EXTENDED REPORT

\title{
Activation of the STAT1 pathway in rheumatoid arthritis
}

\author{
P V Kasperkovitz, N L Verbeet, T J Smeets, J G I van Rietschoten, M C Kraan, T C T M van der \\ Pouw Kraan, P P Tak, C L Verweii
}

Ann Rheum Dis 2004;63:233-239. doi: 10.1136/ard.2003.013276

See end of article for authors' affiliations

\section{Correspondence to:}

P V Kasperkovitz,

Department of Molecular Cell Biology, VU Medical Centre, van der

Boechorststraat 7, 1081 BT

Amsterdam, The

Netherlands;

p.kasperkovitz@vumc.n

Accepted 17 August 2003
Background: Expression of signal transducer and activator of transcription 1 (STAT1), the mediator of interferon (IFN) signalling, is raised in synovial tissue (ST) from patients with rheumatoid arthritis (RA).

Objectives: To determine the extent to which this pathway is activated by phosphorylation in RA synovium. Additionally, to investigate the cellular basis of STAT1 activation in RA ST.

Methods: ST specimens from 12 patients with RA and 14 disease controls (patients with osteoarthritis and reactive arthritis) were analysed by immunohistochemistry, using antibodies to STAT1, tyrosine phosphorylated STAT1, and serine phosphorylated STAT1. Lysates of cultured fibroblast-like synoviocytes stimulated with IFN $\beta$ were analysed by western blotting. Phenotypic characterisation of cells expressing STAT1 in RA ST was performed by double immunolabelling for STAT1 and CD3, CD22, CD55, or CD68. Results: Raised levels of total STAT1 protein and both its activated tyrosine and serine phosphorylated forms were seen in RA synovium as compared with controls. STAT1 was predominantly abundant in T and B lymphocytes in focal inflammatory infiltrates and in fibroblast-like synoviocytes in the intimal lining layer. Raised levels of STAT1 are sustained in cultured RA compared with OA fibroblast-like synoviocytes, and STAT1 serine and tyrosine phosphorylation is rapidly induced upon stimulation with IFN $\beta$.

Conclusion: These results demonstrate activation of the STAT1 pathway in RA synovium by raised STAT1 protein expression and concomitantly increased tyrosine (701) and serine (727) phosphorylation. High expression of STAT1 is intrinsic to RA fibroblast-like synoviocytes in the intimal lining layer, whereas activation of the pathway by phosphorylation is an active process.
A well characterised feature of rheumatoid arthritis (RA) synovial tissue (ST) is a marked increase in cellularity. Factors that contribute to ST hyperplasia are recruitment and retention of inflammatory cells, enhanced cell proliferation, and impaired apoptosis. Cytokines, derived from activated synovial cells have a pivotal role in the regulation of these processes. ${ }^{1}$

Critical in mediating virtually all cytokine driven signalling are the members of the STAT ( signal transducer and activator of transcription) family of transcription factors, which are involved in regulating gene expression and cellular activation, proliferation, and differentiation. ${ }^{2-4}$ Recently, $\mathrm{we}^{5}$ and others $^{6}$ demonstrated raised expression of STATl mRNA and protein in the ST of patients with RA as compared with disease controls, indicating that this pathway might be involved in RA pathogenesis. STATl is essential for interferon (IFN) signalling. IFNs are typically growth inhibitory and promote immune recognition of target cells, and absence of IFN/STATl signalling has been associated with increased susceptibility to infection and tumour formation. ${ }^{7}$ Moreover, STATl has been shown to be essential for growth restraint imposed by IFN $\gamma$ and has important proapoptotic effects through the regulation of caspases. ${ }^{89}$ Type I IFNs are abundant in RA synovium, ${ }^{1}$ and limited expression of IFN $\gamma$ has been shown. ${ }^{1011}$

So far the association of STATl with RA only relies upon the detection of overall STATI mRNA and protein in RA synovium $^{5}{ }^{6}$ and observations in synovial fluid cells. ${ }^{12}$ No information is yet available on the state of activation of STATl in rheumatoid synovium. Activation of STATl involves phosphorylation on tyrosine and serine residues, which are required for the protein to exert its function. Upon binding to the cytokine receptor, cytoplasmic STATl proteins are phosphorylated on tyrosine, after which they can form STATl homodimers or form complexes with other nuclear factors, for example STATI/STAT2/IRF9 heterotrimers, and subsequently translocate to the nucleus to initiate transcription. In addition, serine phosphorylation of STATl is required for full transcriptional activity. ${ }^{13}{ }^{14}$

In the present work we investigated the activation of STATl protein in RA ST by studying its phosphorylation compared with ST from disease controls, including patients with osteoarthritis (OA) and reactive arthritis (ReA). In addition, we characterised the expression and activation of STATl in the various cell types in RA ST.

\section{MATERIALS AND METHODS \\ Patients}

ST was obtained from the actively inflamed knee joints of 26 patients, including 12 patients with RA (1987 American College of Rheumatology (ACR) criteria ${ }^{15}$ ), 7 patients with inflammatory OA (1987 criteria $^{16}$ ), and 7 patients with ReA. All material was obtained in the early 1990s; at that time ST could be obtained from all patients before disease modifying antirheumatic drug (DMARD) treatment was initiated. Table 1 presents the clinical and demographic data of these patients. All patients gave their informed consent and the study protocol was approved by the medical ethics committee.

Knee joint arthroscopy and synovial biopsies In all patients an arthroscopy was performed under local anaesthesia using a small bore, $2.7 \mathrm{~mm}$ arthroscope (Storz)

\footnotetext{
Abbreviations: ACR, American College of Rheumatology; AP, alkaline phosphatase; BSA, bovine serum albumin; DMARD, disease modifying antirheumatic drug; FCS, fetal calf serum; FITC, fluorescein isothiocyanate; HPF, high power field; HRP, horseradish peroxidase; IFM, immunofluorescence microscopy; IFN, interferon; IHC, immunohistochemistry; IOD, integrated optical density; $O A$, osteoarthritis; RA, rheumatoid arthritis; ReA, reactive arthritis; ST, synovial tissue; STAT, signal transducer and activator of transcription
} 
Table 1 Demographic and clinical data of the 12 patients with RA and the control patients, including seven patients with $O A$ and seven patients with $\operatorname{ReA}$, who were studied for expression of STATl and its tyrosine and serine phosphorylated forms. All material was collected in the early 1990s; at that time synovial tissue could be obtained from all patients before DMARD treatment was initiated

\begin{tabular}{|c|c|c|c|c|c|c|c|c|c|}
\hline Patient & $\begin{array}{l}\text { Diagnosis } \\
\text { (RA/OA/ReA) }\end{array}$ & $\begin{array}{l}\text { Age } \\
\text { (years) }\end{array}$ & Sex (M/F) & $\begin{array}{l}\text { Disease duration } \\
\text { (months) }\end{array}$ & Drugs & $\begin{array}{l}\text { CRP } \\
(\mathrm{mg} / \mathrm{ll})\end{array}$ & $\begin{array}{l}\text { ESR } \\
(\mathrm{mm} / 1 \mathrm{st} \mathrm{h})\end{array}$ & $\begin{array}{l}\text { RF } \\
(+/-)\end{array}$ & $\begin{array}{l}\text { Erosions } \\
(+/-)\end{array}$ \\
\hline 1 & RA & 47 & $M$ & 6 & - & 10 & 17 & + & - \\
\hline 2 & RA & 80 & $\mathrm{~F}$ & 4 & NSAID* & 47 & ND & + & + \\
\hline 3 & RA & 76 & $\mathrm{~F}$ & 8 & NSAID & 11 & 46 & - & + \\
\hline 4 & RA & 73 & $\mathrm{~F}$ & 4 & NSAID & 18 & 72 & + & + \\
\hline 5 & RA & 57 & $\mathrm{~F}$ & 4 & NSAID & 68 & 81 & + & + \\
\hline 6 & RA & 66 & $\mathrm{~F}$ & 24 & NSAID & 19 & 37 & + & + \\
\hline 7 & RA & 60 & $\mathrm{~F}$ & 180 & NSAID & 53 & 108 & + & + \\
\hline 8 & RA & 58 & $\mathrm{~F}$ & 192 & NSAID & 48 & 74 & + & + \\
\hline 9 & RA & 44 & $M$ & 2 & NSAID & 22 & 33 & + & - \\
\hline 10 & RA & 54 & $\mathrm{~F}$ & 108 & NSAID & 141 & 93 & + & + \\
\hline 11 & RA & 63 & $M$ & 4 & NSAID & 40 & 65 & + & + \\
\hline 12 & RA & 71 & $\mathrm{~F}$ & 12 & NSAID & 49 & ND & + & ND \\
\hline 13 & OA & 77 & $\mathrm{~F}$ & 0 & - & 7 & 17 & - & - \\
\hline 14 & $O A$ & 76 & $\mathrm{~F}$ & 240 & NSAID & 11 & 24 & - & - \\
\hline 15 & $O A$ & 73 & $\mathrm{~F}$ & 60 & - & 7 & 18 & - & - \\
\hline 16 & $O A$ & 74 & $\mathrm{~F}$ & 192 & NSAID & 8 & 14 & + & - \\
\hline 17 & OA & 54 & $\mathrm{~F}$ & 6 & - & 6 & 14 & - & - \\
\hline 18 & OA & 67 & $M$ & 8 & NSAID & 3 & 10 & - & - \\
\hline 19 & $O A$ & 77 & $M$ & 12 & - & ND & 43 & - & - \\
\hline 20 & $\operatorname{Re} A$ & 37 & $\mathrm{~F}$ & 3 & - & 3 & 14 & - & - \\
\hline 21 & $\operatorname{ReA}$ & 27 & $M$ & 1 & NSAID & ND & ND & ND & - \\
\hline 22 & $\operatorname{ReA}$ & 44 & $M$ & 18 & - & 4 & 9 & - & - \\
\hline 23 & $\operatorname{ReA}$ & 33 & $M$ & 11 & - & 3 & 3 & - & - \\
\hline 24 & $\operatorname{ReA}$ & 39 & $\mathrm{~F}$ & 14 & NSAID & 7 & 0 & - & - \\
\hline 25 & $\operatorname{ReA}$ & 22 & $M$ & 1 & NSAID & ND & ND & - & - \\
\hline 26 & $\operatorname{ReA}$ & 67 & $\mathrm{~F}$ & 4 & - & 23 & 24 & - & - \\
\hline
\end{tabular}

RA, rheumatoid arthritis; OA, osteoarthritis; ReA, reactive arthritis; NSAID, non-steroidal anti-inflammatory drug; CRP, C reactive protein; ESR, erythrocyte sedimentation rate; RF, rheumatoid factor; ND, not determined.

and using an infrapatellar skin portal for macroscopic examination of the synovium and a second suprapatellar portal for the biopsy procedure. ${ }^{17}$ Synovial biopsy samples were obtained from multiple regions $(\geqslant 6)$ using a $2.5 \mathrm{~mm}$ grasping forceps (Storz). Tissue samples were embedded en bloc in Tissue Tek OCT compound (Miles Diagnostics, Elkhart, IN) and snap frozen in liquid nitrogen. The frozen blocks were stored in liquid nitrogen until sectioned for staining. Sections $(5 \mu \mathrm{m})$ were cut in a cryostat and mounted on glass slides (Star Frost adhesive slides, Knittelgläser, Braunschweig, Germany); the slides were air dried at room temperature, carefully packed, and sealed and stored at $-80^{\circ} \mathrm{C}$ until immunohistochemical staining was performed.

\section{Antibodies}

Serial sections were stained using the following monoclonal antibodies and diluted as indicated for immunohistochemistry (IHC) and immunofluorescence microscopy (IFM): antiSTAT1, 1:160 (BD Transduction Laboratories); anti-phosphoSTATl-tyrosine (Y701), 1:40 (Zymed Laboratories Inc, San Francisco, CA); anti-CD3, 1:320 for IHC, 1:100 for IFM (SK4, Becton Dickinson, San Jose, CA); anti-CD22, 1:80 for IHC, 1:50 for IFM (CLB-B-Ly, 6B11, Sanquin, Amsterdam, The Netherlands), anti-CD55, 1:20 for IHC, 1:25 for IFM (Bric 110, Sanquin); anti-CD68, 1:320 for IHC, 1:200 for IFM (KP1, DAKO, Glostrup, Denmark). A polyclonal antibody was used to detect phospho-STATl-serine (S727), 1:1000 (Upstate Biotechnology).

\section{Immunohistochemistry}

Sections were brought to room temperature, dried, and then fixed with acetone for 10 minutes. Endogenous peroxidase activity was inhibited using $0.1 \%$ sodium azide and $0.3 \%$ hydrogen peroxidase in phosphate buffered saline. Staining was performed as described previously. ${ }^{18}$ After a primary incubation step with the antibody of interest, bound antibody was detected using a three step alkaline phosphatase (AP) method for CD3, CD22, CD55, CD68. An immunoperoxidase method was used for STATl and phospho-STATs. For these antibodies, except for STATl, staining was performed using biotinylated tyramine (Perkin Elmer Life Sciences, Boston, MA) for amplification.

For double IHC, sections were incubated with anti-STATl overnight. Horseradish peroxidase (HRP) conjugated goatantimouse was added for 30 minutes, followed by swineantigoat-HRP for 30 minutes. To prevent binding to excess antimouse antibody, sections were blocked with $10 \%$ normal mouse serum (Sanquin) for 15 minutes. Subsequently, sections were incubated for 60 minutes with fluorescein isothiocyanate (FITC) conjugated anti-CD3, -CD22, -CD55, or -CD68, followed by rabbit-anti-FITC (DAKO) and swineantirabbit-AP, each for 30 minutes. HRP activity was detected using hydrogen peroxidase as substrate and aminoethylcarbazole as dye (Sigma, St Louis, MO). AP activity was detected using AP substrate kit III (Vector Laboratories, Inc, Burlingame, CA 94010). Double stained slides were not counterstained; single stained slides were counterstained with Mayer's haematoxylin (Sigma) and mounted in Kaiser's glycerol gelatin (Merck, Darmstadt, Germany).

\section{Digital image analysis}

Sections analysed by immunohistochemistry were coded and assessed by digital image analysis in random order as described previously. ${ }^{19}$ Briefly, three separate representative regions, including the intimal lining layer and synovial sublining, were chosen for the evaluation of each section. Six consecutive high power fields (HPFs) from each region were captured and digitised, resulting in a total of 18 HPFs ( surface area $\sim 2.1 \mathrm{~mm}^{2}$ ). Subsequently, sections were 
examined using a specialised algorithm written in the program language QUIPS operating a Qwin based (Qwin Pro V2.4; Leica, Cambridge, UK) computer assisted, colour video image analysis system. ${ }^{19} 20$ To quantify staining for STAT1, STATI-P-Tyr, and STATI-P-Ser in the analysed regions, integrated optical density (IOD) was calculated as the product of staining area and intensity ${ }^{21}$ and presented as $\mathrm{IOD} / \mathrm{mm}^{2}$ tissue. The total cell count of the measured regions was determined by quantification of nuclear counterstaining, which allowed for normalisation for cellularity in all regions.

\section{Fluorescence microscopy}

Double immunofluorescence was performed on sections of four patients with RA. The staining procedure used is a modification of the method described previously. ${ }^{18}$ Firstly, sections were incubated with anti-STATl monoclonal antibody, followed by incubation with tetramethylrhodamine isothiocyanate (TRITC) conjugated goat-antimouse IgGl antibody (Nordic, Tilburg, The Netherlands). After use of $10 \%$ normal mouse serum (Sanquin) as blocking serum, incubation with FITC labelled anti-CD3, -CD22, -CD55, or -CD68 was performed on serial sections. Sections were embedded in mounting medium (Vectashield, Vector Labs Inc) and analysed by two independent assessors (PVK and TJS). During the analysis, all cells that were double positive for STATl and the respective CD marker were counted and given as a percentage of the absolute number of either $\mathrm{CD} 3+$, CD22+, CD55+, or CD68+ cells in the biopsy specimens.

\section{Cell culture and stimulation}

Fibroblast-like synoviocytes were obtained from synovial biopsy samples of patients with RA who fulfilled the criteria of the $\mathrm{ACR}^{15}$ and patients with OA (1987 criteria $\left.{ }^{16}\right)$. After enzymatic digestion, fibroblast-like synoviocytes were grown in culture flasks in Dulbecco's modified Eagle's medium supplemented with $10 \%$ fetal calf serum (FCS), and cells were routinely split. Experiments were performed using third to sixth passage fibroblast-like synoviocytes. At this time, $<2 \%$ contaminating lymphocytes, NK cells, or macrophages were present. The day before an experiment, cells were replated in medium containing $0.5 \%$ FCS. Stimulation was performed for 30 minutes in six-well dishes using recombinant human IFN $\beta$ (Sanquin) at a final concentration of 250 $\mathrm{U} / \mathrm{ml}$. Cell extracts were prepared in ice cold RIPA buffer (20 mM Tris; $150 \mathrm{nM} \mathrm{NaCl;} 1 \%$ sodium deoxycholic acid; $1 \%$ NP-40; $0.1 \%$ sodium dodecyl sulphate; $50 \mathrm{mM} \mathrm{NaF} ; 250 \mu \mathrm{M}$ $\mathrm{Na}_{3} \mathrm{VO}_{4} ; 10 \mathrm{mM} \mathrm{Na}{ }_{2} \mathrm{PHO}_{4} ; 1$ pill/50 ml of Complete (Roche) protein inhibitor) and kept on ice on a shaking platform for 30 minutes. After centrifugation at $4000 \mathrm{rpm}$ for 10 minutes, supernatants were transferred to a fresh tube and frozen at $-20^{\circ} \mathrm{C}$ until further use.

\section{Western blot analysis}

Cell lysates of fibroblast-like synoviocytes were corrected for total protein content ( $35 \mu \mathrm{g}$ total protein per lane) and fractionated on $7.5 \%$ sodium dodecyl sulphate-polyacrylamide gels and transferred to nitrocellulose membranes. Membranes were blocked in Tris buffered saline-Tween/3\% bovine serum albumin (BSA) for 1 hour and then incubated with the antibodies described above that were directed against STATl, phospho-STATl-tyrosine (Y701), or phospho-STAT1-serine(S727) at a dilution of 1:500 in Tris buffered saline-Tween/1\% BSA. Enhanced chemiluminescence was used for detection.

\section{Statistical analysis}

The Mann-Whitney two sample test was used for comparison of RA ST with control ST.

\section{RESULTS}

\section{Activation of the STAT 1 pathway in RA synovium}

To obtain insight into the extent of activation of the STATl pathway in RA synovium, immunohistochemical studies were performed on the ST of 12 patients with RA and 14 disease controls, including 7 patients with OA and 7 with ReA (table 1). Only patients who had not yet been treated with DMARDs were included in the study, and the RA patient group consisted of patients with both early and longstanding RA. Serial sections were stained for STATl and both its phosphorylated forms, phospho-STATl(Y701) and phosphoSTATl(S727). STATl expression and phosphorylation was predominantly abundant in the intimal lining layer and in focal inflammatory infiltrates in the synovial sublining (fig lA).

To make a quantitative comparison between the patients with RA and the control group, expression was quantified by digital image analysis. ${ }^{19}{ }^{20}$ Comparison of RA ST with ST of disease controls showed that STATl protein expression was raised in RA ST (expressed as mean (SD) IOD per $\mathrm{mm}^{2}$ of tissue, $209(214) v 24$ (29) in disease controls, $\mathrm{p}=0.0097$, data not shown), which is consistent with our previously reported results. ${ }^{5}$ Normalisation to the total number of cells present in the sections shows that the difference is still highly significant $(p=0.014)$, indicating that this effect could not merely be explained by differences in leucocyte infiltration. In addition, we found that STATl phosphorylation on tyrosine was significantly increased in RA ST as compared with controls $(p=0.017)$ as well as phosphorylation on serine $(p=0.029)$ (fig $1 B)$. Calculation of the ratio of phosphorylated STATl to total STATl present for each patient showed no significant differences between patients with RA and disease controls $(p=0.70$ and $p=0.52$ for STATl-P-Tyr/STATl and STATl-P-Ser/STATl, respectively), which suggests that activation by phosphorylation may increase concomitantly with STATl expression.

\section{STAT 1 is differentially expressed in RA synovial tissue} To evaluate specifically which cells in the different synovial compartments express STAT1, immunohistochemical double labelling was performed on the ST of four patients with RA using antibodies to detect T cells (anti-CD3), B cells (antiCD22), fibroblast-like synoviocytes (anti-CD55), and macrophages (anti-CD68).

In the synovial sublining, STATl was mainly localised in both $\mathrm{B}$ and $\mathrm{T}$ lymphocytes (figs $2 \mathrm{~A}$ and $\mathrm{B}$ ). Focal inflammatory infiltrates of $\mathrm{CD} 22+\mathrm{B}$ cells were found that exhibited strongly positive staining for STATl (fig 2A). High STATl expression was also seen in CD3+ T lymphocytic aggregates. Interestingly, in one patient both STATl positive T lymphocytic aggregates and $\mathrm{T}$ lymphocytic aggregates that were entirely negative for STATl were seen (fig 2B). CD68+ macrophages were abundant around lymphocyte clusters and in the intimal lining layer. Regardless of their position in the tissue, staining for STATl was relatively limited in these cells (fig 2D). In contrast, CD55+ fibroblast-like synoviocytes in the intimal lining layer stained strongly positive for STATl (fig 2C).

To make a quantitative assessment of the percentage of STATl+cells in these synovial cell populations, double immunofluorescence was performed (fig 3A) on the ST of four patients with RA who were not included in the previous analysis. The results confirmed the observation that STATl is expressed by B lymphocytes (fig 3B; mean (SD) STATl+ cells of total CD22+ cells $=45(5) \%)$, T lymphocytes $(54(8) \%)$, and the majority of fibroblast-like synoviocytes (87 (9)\%). Only a limited number of macrophages (18 (15)\%) were found to be STATl+. Taken together, these results indicate 
A

RA

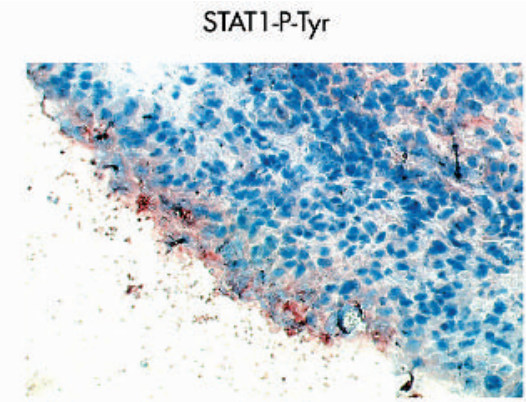

$\mathrm{OA}$

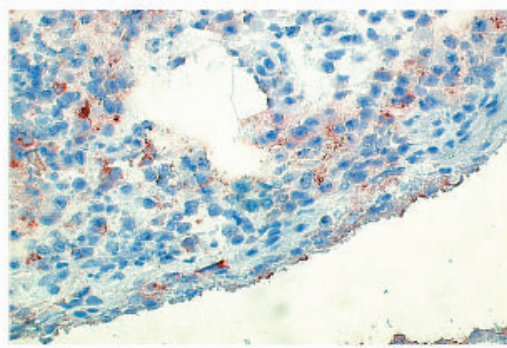

B

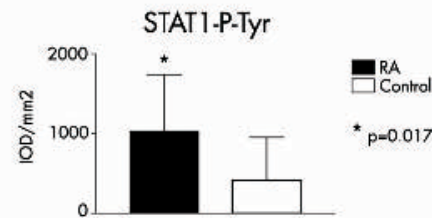

STAT1-P-Ser
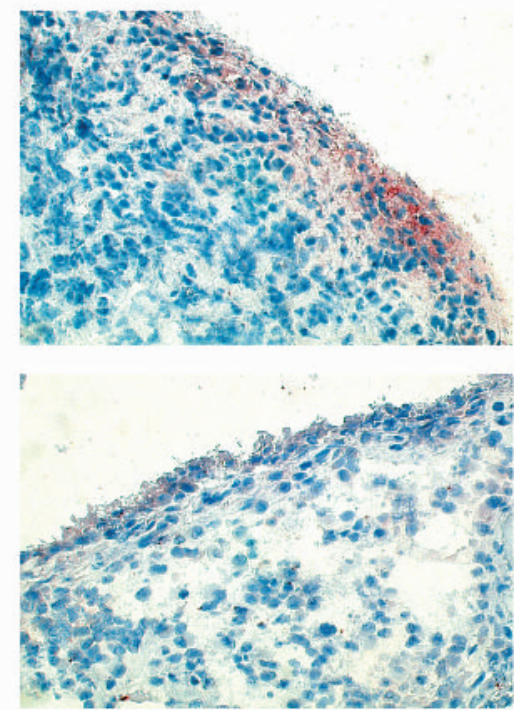

STATI-P-Ser

Figure 1 Increased STAT1 phosphorylation on tyrosine and serine in RA ST as compared with controls. Serial ST sections from 12 patients with RA and 14 controls were stained for STAT1-phospho-tyrosine and STAT1-phospho-serine using aminoethylcarbazole as dye (A) representative sections are shown. Counterstaining was performed using Mayer's haematoxylin. (Original magnification $\times 400$.) Sections were analysed using computer assisted digital image analysis (B). Results are shown as means, errors bars indicate SD; on the y axis the mean IOD per $\mathrm{mm}^{2}$ of tissue (see "Materials and methods") is shown.

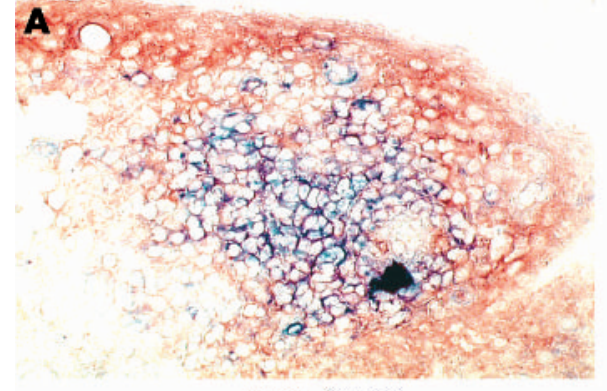

STAT1/CD22

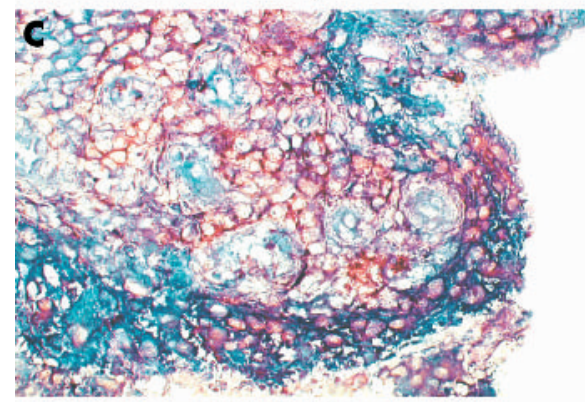

STAT1/CD55

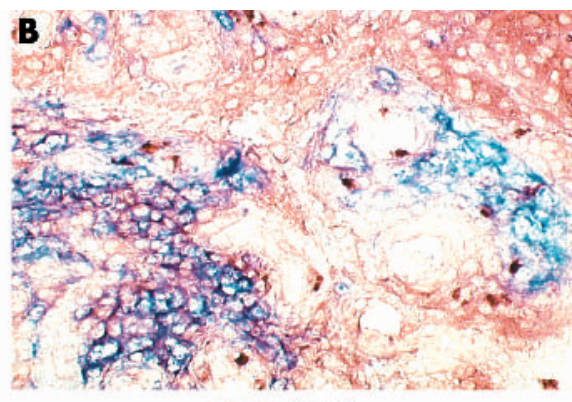

STAT 1/CD3

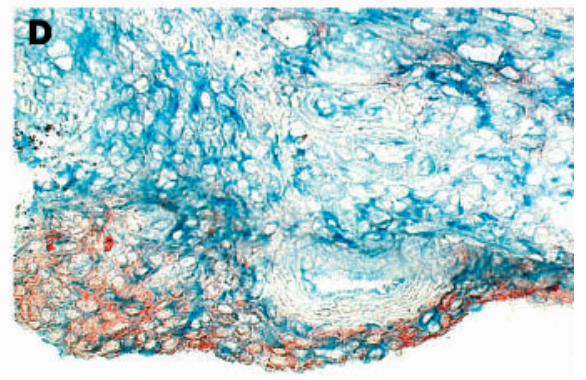

STAT1/CD68

Figure 2 Immunohistochemical double labelling of the ST of four patients with RA (table 1; patients Nos 4, 5, 7, and 13; representative sections are shown) for STAT1 and CD22+ B cells (A), CD3+ T cells (B), CD55+ fibroblast-like synoviocytes (C), or CD68+ macrophages (D). STAT1 was detected using aminoethylcarbazole as dye (red) and CD molecules were detected using AP substrate (blue); no counterstaining was performed (see "Materials and methods"). (Original magnification $\times 400$.) 
A

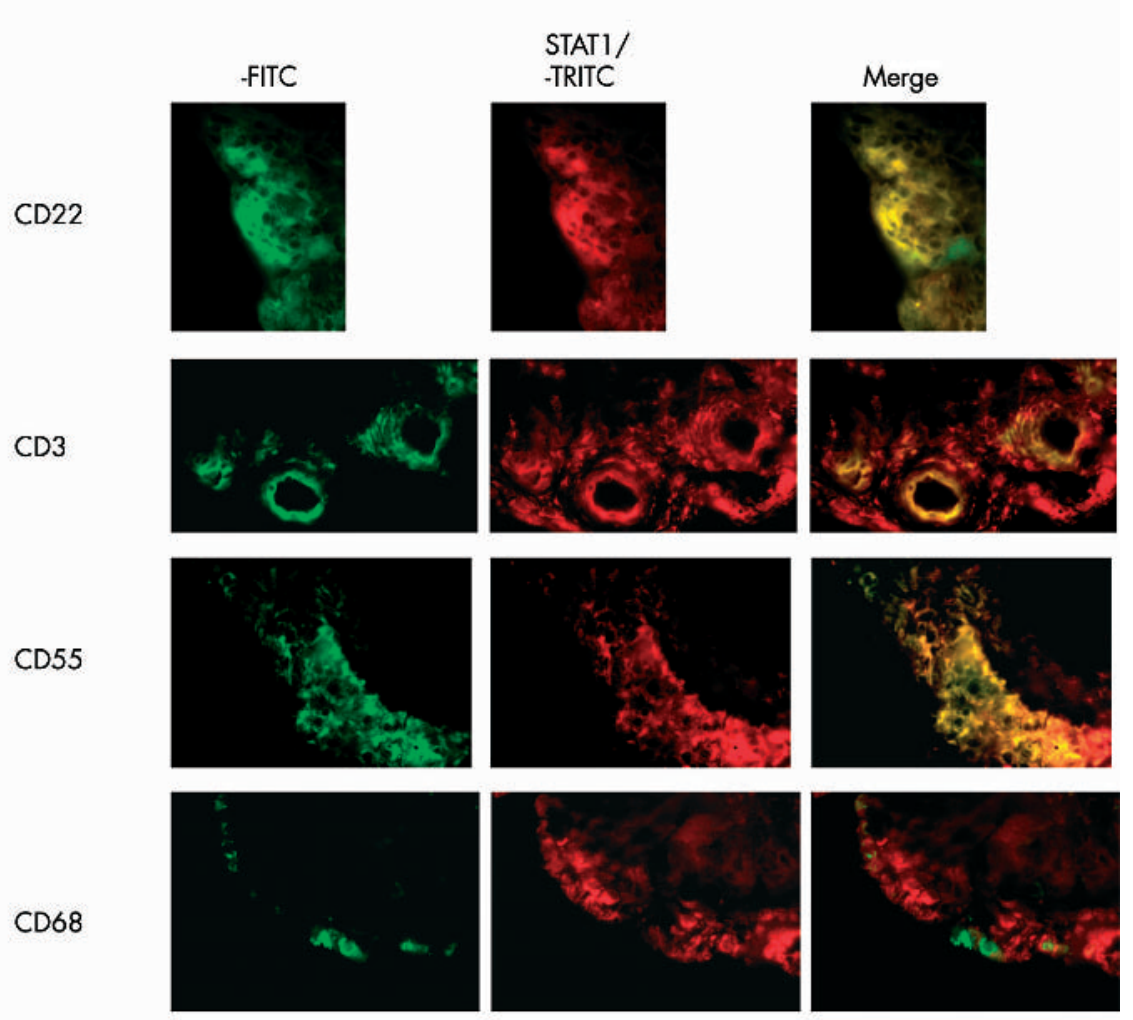

B

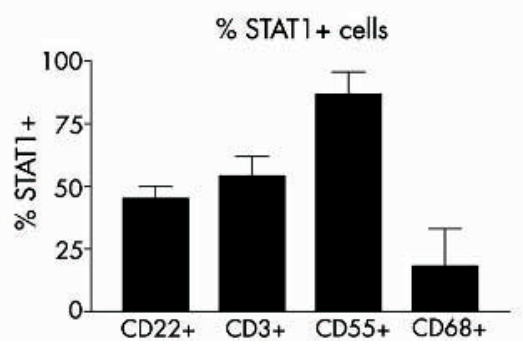

that the abundance of STATl in the intimal lining layer is predominantly due to expression by fibroblast-like synoviocytes.

\section{STAT 1 expression and activation in fibroblast-like synoviocytes}

To validate our in vivo observations, we assessed the expression of STATI in RA and OA fibroblast-like synoviocytes by immunoblot analysis of lysates of cultured cells. These studies disclosed higher expression of STATl in RA fibroblast-like synoviocytes than in OA synoviocytes (fig 4), which is consistent with our in vivo observations in whole ST. Interestingly, although expression of STATl was sustained in vitro, tyrosine phosphorylation was absent and only low basal levels of serine phosphorylation were found in cultured fibroblast-like synoviocytes from both patients with RA and OA. Stimulation with IFN $\beta$ rapidly induced both tyrosine and serine phosphorylation. These results show that whereas raised expression of STATl is a stable, instrinsic feature of RA fibroblast-like synoviocytes, activation of STATl by phosphorylation is not sustained in culture. Induction of phosphorylation on both tyrosine and serine residues appears to be an active process, which can be induced by IFN $\beta$, a cytokine that is abundantly expressed in RA synovium.
Figure 3 Double immunofluorescence was performed on the ST of four patients with RA (table 1; patients Nos $1,2,3$, and 10). (A) STAT1 (tetramethylrhodamine) and CD22+ B cells, CD3+ T cells, CD55+ fibroblastlike synoviocytes, or CD68+ macrophages (fluorescein). No counterstaining was performed. (Original magnification $\times 400$.) (B) Percentage STAT1+ cells of, respectively, total $\mathrm{CD} 22+, \mathrm{CD} 3+$, CD55+, or CD68+ cells. Bars represent mean $(S D)(n=4)$.

\section{DISCUSSION}

The prime aim of the present study was to extend our understanding of the expression and activation of STATl in RA. Previously, $w^{5}$ and others ${ }^{6}$ reported that STATl expression is raised in RA synovium as compared with controls, and STATl activation has been shown in rheumatoid synovial fluid cells. ${ }^{12}$ In the present work we provide evidence for activation of the STATl pathway in RA synovium and define the cell types that express STATl. Raised expression of STATl appears to be intrinsic to RA fibroblast-like synoviocytes, whereas activation by phosphorylation is an active process.

Regulation of signalling through the Jak-STAT pathway is complex and occurs at several levels within the cell. Up regulation of STATl mRNA and protein expression in response to stimulation with IFNs have been described previously. ${ }^{62}$ Key post-translational modifications include tyrosine and serine phosphorylation, which are required for dimerisation and full transcriptional activity of STATs. ${ }^{13}{ }^{14}$ Our results demonstrate that activation of STATl in the RA inflamed joint is not only reflected by increased expression of STATl but also by increased phosphorylation on both tyrosine (701) and serine (727) residues. The fact that 


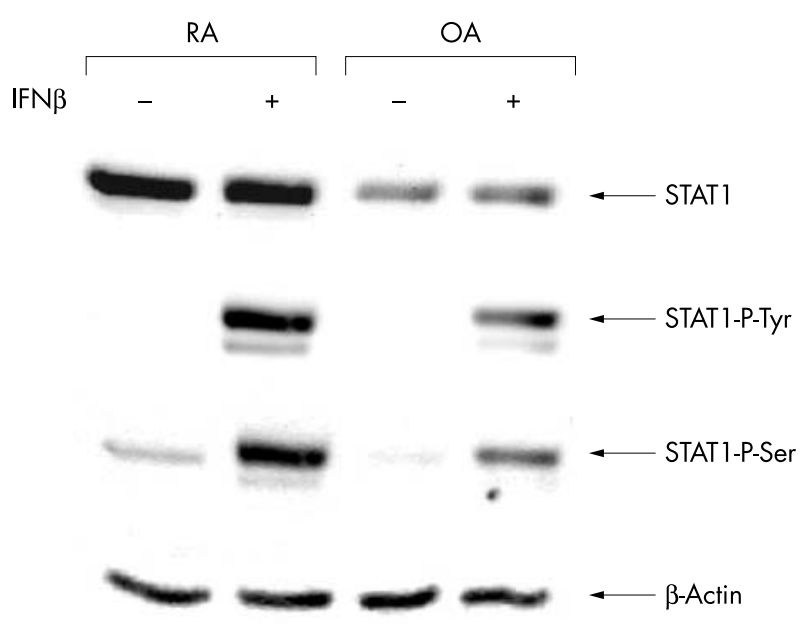

Figure 4 STAT1 expression is raised in RA compared with OA fibroblast-like synoviocytes (top panel) and STATI tyrosine and serine phosphorylation are induced by stimulation with IFN $\beta$ (second and third panels). Fourth passage RA and OA synoviocytes were treated with IFN $\beta$ $(250 \mathrm{U} / \mathrm{ml})$. Cell extracts were prepared 30 minutes after cytokine stimulation, corrected for total protein content, and analysed by immunoblotting.

STATl activation is less pronounced in patients with OA and ReA may reflect the differential expression of IFN $\beta$ and IFN $\gamma$ between diseases. These findings are in line with our microarray results, which demonstrated an increased expression of IFN-induced genes in RA STs that display up regulation of STATI mRNA. ${ }^{5}$ The observation that ratios of phosphorylated STATl to total STATl for each patient are comparable in patients with RA and controls suggests that up regulation of STATl protein expression and its activation by phosphorylation are concomitant events. Whether this is really true, however, can only be determined if extensive studies at the single cell level are performed.

In accordance with our microarray gene profiling results, $^{53}$ we observed considerable variation in STATl expression and activation among patients with RA and controls. In the patient group studied patients with both early and longstanding RA were included, and no correlations between STATl activation and the duration of disease or other clinical variables (table 1) were found. This, however, may be due to the relatively small number of patients studied. We investigated the expression profile of STATl in the different synovial compartments in patients with RA by using two different double labelling techniques. In the synovial sublining we detected increased STATl protein expression in focal inflammatory infiltrates of both $\mathrm{B}$ and $\mathrm{T}$ lymphocytic origins. Interestingly, in one patient we detected a STATl positive perivascular T lymphocytic aggregate (fig 3A, second panel). Although the majority of lymphocytic infiltrates in RA were STATl positive, in some aggregates STATl expression was entirely absent. This can be seen in fig 2, where a STATl positive T lymphocyte aggregate and an adjacent STAT1 negative aggregate are shown (fig 2B). These findings suggest that STATl is differentially expressed in synovial lymphocytes, which may reflect the state of activation and cellular differentiation of these cells.

STATl expression was also abundant in the intimal lining layer. The vast majority of fibroblast-like synoviocytes in the intimal lining layer expressed high levels of STATl, whereas only limited expression of STATl was found in macrophages, regardless of their position in either intimal lining layer or synovial sublining. This is particularly interesting in light of the recent report by $\mathrm{Hu}$ et $a l^{6}{ }^{6}$ who demonstrated the existence of a delicate regulatory system for STATI in IFN $\gamma$ signalling. They showed that exposure of macrophages to subthreshold concentrations of IFN $\gamma$ sensitises these cells to subsequent IFN $\gamma$ stimulation, which results in increased STATl expression. To find supporting evidence for the occurrence of this mechanism in vivo, they stated that STATl protein expression is increased in RA synovium, particularly in the intimal lining layer. In their rationale they implied that this might be due to intimal macrophages displaying increased STATl expression as a result of the IFN $\gamma$ responses that lead to tissue abnormality in RA. However, our results demonstrate that the abundance of STATl in the intimal lining predominantly results from STAT1 expression by fibroblast-like synoviocytes.

It has been suggested that RA fibroblast-like synoviocytes not only respond to stimulation by proinflammatory cytokines but also show intrinsic molecular changes that are maintained in the absence of external stimuli. ${ }^{24}{ }^{25}$ Here we demonstrated that increased expression of STATl in RA compared with OA fibroblast-like synoviocytes is sustained in culture. On the other hand, phosphorylation of STATl is almost completely lost in vitro, indicating that this is an active process that can be induced by cytokines in RA synovium. This notion is supported by the observation that STATl phosphorylation in fibroblast-like synoviocytes is rapidly restored upon stimulation with the type I interferon IFN $\beta$. IFN $\beta$ is produced by fibroblast-like synoviocytes and abundant in synovium. Therefore, conceivably, this mechanism of STATl activation takes place in vivo in fibroblast-like synoviocytes. Type I interferons are believed to have immunosuppressive functions, including antiangiogenic effects. On the other hand, IFN $\beta$ produced by fibroblast-like synoviocytes can act as a survival factor for $\mathrm{T}$ cells in the rheumatoid joint. ${ }^{26}$ It is interesting to note that stimulation with IFN $\gamma$ also induced STATl phosphorylation in fibroblastlike synoviocytes (data not shown). Because IFN $\gamma$ expression is absent in the synovial lining this mechanism of STATl activation may rather be of importance in other synovial cell types.

Evidence for the importance of the Jak-STAT pathway in RA pathogenesis is accumulating, and has so far mainly been focused on the role of STAT3 and its growth promoting role. Accordingly, Shouda et al demonstrated that blockade of STAT3 by overexpression of SOCS3, a STAT3-induced inhibitor of Jak-STAT signalling, suppressed experimental arthritis. ${ }^{27}$ In contrast, an important effector function of STATl is its growth inhibitory effect. STATl is required for the growth restraint imposed by IFN $\alpha$ and IFN $\gamma^{28}$ and the promotion of apoptosis. ${ }^{82} 30$ Krause et al showed that the proapoptotic action of STATl is antagonised by STAT3, ${ }^{31}$ which appears to be essential for RA synoviocyte survival. This is in line with the notion that STATl and STAT3 can serve as a tumour suppressor and a tumour promoter, respectively. ${ }^{7}$ Because our data demonstrate that besides the STAT3 signalling pathway the STATl pathway also is activated in fibroblast-like synoviocytes, it is tempting to speculate that the proapoptotic signals delivered by STATI in these cells in vivo are not strong enough to effectively counteract the STAT3 derived survival signals.

STATl may have a role as transcriptional activator as a STATl homodimer or as a constituent of a complex involving other factors, for example the STATI/STAT2/IRF9 heterotrimer. For the future it is challenging to know in which form STATl exerts its biological effects in ST, and what part activation of STATl plays in the fate of infiltrating lymphocytes. A better understanding of the balance of signals delivered through the different STAT pathways by dissecting the individual pathways and evaluating their contributions to either cell survival or growth arrest may 
contribute to elucidating the disease mechanisms that are at play in RA.

\section{ACKNOWLEDGEMENTS}

Part of this study was financially supported by the Dutch Arthritis Foundation.

\section{Authors' affiliations}

P V Kasperkovitz, N L Verbeet, J G I van Rietschoten, T C T M van der Pouw Kraan, C L Verweii, Department of Molecular Cell Biology, VU Medical Centre/VU University Amsterdam, 1081 BT Amsterdam, The Netherlands

P V Kasperkovitz, T J Smeets, M C Kraan, P P Tak, Division of Clinical Immunology and Rheumatology, Academic Medical Centre/University of Amsterdam, 1105 AZ Amsterdam, The Netherlands

\section{REFERENCES}

1 Andreakos ET, Foxwell BM, Brennan FM, Maini RN, Feldmann M. Cytokines and anti-cytokine biologicals in autoimmunity: present and future. Cytokine Growth Factor Rev 2002; 13:299-313.

2 Bromberg J, Darnell JE Jr. The role of STATs in transcriptional control and their impact on cellular function. Oncogene 2000;19:2468-73.

3 O'Shea JJ, Gadina M, Schreiber RD. Cytokine signaling in 2002: new surprises in the Jak/Stat pathway. Cell 2002;109(suppl):S121-31.

4 Kisseleva T, Bhattacharya S, Braunstein J, Schindler CW. Signaling through the JAK/STAT pathway, recent advances and future challenges. Gene 2002;285: 1-24.

5 van der Pouw Kraan TC, Van Gaalen FA, Kasperkovitz PV, Verbeet NL, Smeets TJ, Kraan MC, et al. Rheumatoid arthritis is a heterogeneous disease: evidence for differences in the activation of the STAT- 1 pathway between rheumatoid tissues. Arthritis Rheum 2003:48:2132-45.

6 Hu X, Herrero C, Li WP, Antoniv TT, Falck-Pedersen E, Koch AE, et al. Sensitization of IFN-gamma Jak-STAT signaling during macrophage activation. Nat Immunol 2002;3:859-66.

7 Shankaran V, lkeda H, Bruce AT, White JM, Swanson PE, Old U, et al. IFNgamma and lymphocytes prevent primary tumour development and shape tumour immunogenicity. Nature 2001;410:1107-11.

8 Chin YE, Kitagawa M, Kuida K, Flavell RA, Fu XY. Activation of the STAT signaling pathway can cause expression of caspase 1 and apoptosis. Mol Cell Biol 1997; 17:5328-37.

9 Shen Y, Devgan G, Darnell JE Jr, Bromberg JF. Constitutively activated Stat3 protects fibroblasts from serum withdrawal and UV-induced apoptosis and antagonizes the proapoptotic effects of activated Stat1. Proc Natl Acad Sci USA 2001;98:1543-8.

10 Fonseca JE, Edwards JC, Blades S, Goulding NJ. Macrophage subpopulations in rheumatoid synovium: reduced CD163 expression in CD4+ T lymphocyterich microenvironments. Arthritis Rheum 2002;46:1210-16.

11 Smeets TJ, Dolhain RJ, Breedveld FC, Tak PP. Analysis of the cellular infiltrates and expression of cytokines in synovial tissue from patients with rheumatoid arthritis and reactive arthritis. J Pathol 1998;186:75-81.

12 Yokota A, Narazaki M, Shima Y, Murata N, Tanaka T, Suemura M, et al. Preferential and persistent activation of the STAT1 pathway in rheumatoid synovial fluid cells. J Rheumatol $2001 ; 28$ :1952-9.
13 Decker T, Kovarik P. Serine phosphorylation of STATs. Oncogene 2000; 19:2628-37.

14 Decker T, Kovarik P. Transcription factor activity of STAT proteins: structural requirements and regulation by phosphorylation and interacting proteins. Cell Mol Life Sci 1999:55:1535-46.

15 Arnett FC, Edworthy SM, Bloch DA, McShane DJ, Fries JF, Cooper NS, et al. The American Rheumatism Association 1987 revised criteria for the classification of rheumatoid arthritis. Arthritis Rheum 1988;31:315-24

16 Altman R, Alarcon G, Appelrouth D, Bloch D, Borenstein D, Brandt K, et al. The American College of Rheumatology criteria for the classification and reporting of osteoarthritis of the hip. Arthritis Rheum 1991;34:505-14.

17 Kraan MC, Reece RJ, Smeets TJ, Veale DJ, Emery P, Tak PP. Comparison of synovial tissues from the knee joints and the small joints of rheumatoid arthritis patients: implications for pathogenesis and evaluation of treatment. Arthritis Rheum 2002;46:2034-8

18 Tak PP, van der Lubbe PA, Cauli A, Daha MR, Smeets TJ, Kluin PM, et al. Reduction of synovial inflammation after anti-CD4 monoclonal antibody treatment in early rheumatoid arthritis. Arthritis Rheum 1995;38:1457-65.

19 Kraan MC, Haringman JJ, Ahern MJ, Breedveld FC, Smith MD, Tak PP. Quantification of the cell infiltrate in synovial tissue by digital image analysis. Rheumatology (Oxford) 2000;39:43-9.

20 Kraan MC, Smith MD, Weedon H, Ahern MJ, Breedveld FC, Tak PP. Measurement of cytokine and adhesion molecule expression in synovial tissue by digital image analysis. Ann Rheum Dis $2001 ; 60: 296-8$.

21 Youssef PP, Triantafillou S, Parker A, Coleman M, Roberts-Thomson PJ, Ahern $M J$, et al. Variability in cytokine and cell adhesion molecule staining in arthroscopic synovial biopsies: quantification using color video image analysis. J Rheumatol 1997;24:2291-8.

22 Lehtonen A, Matikainen S, Julkunen I. Interferons up-regulate STAT1, STAT2, and IRF family transcription factor gene expression in human peripheral blood mononuclear cells and macrophages. J Immunol 1997; 159:794-803.

23 van der Pouw Kraan TC, Van Gaalen FA, Huizinga TW, Pieterman E Breedveld FC, Verweij CL. Discovery of distinctive gene expression profiles in rheumatoid synovium using cDNA microarray technology: evidence for the existence of multiple pathways of tissue destruction and repair. Genes Immun 2003:4:187-96.

24 Yamanishi $Y$, Firestein GS. Pathogenesis of rheumatoid arthritis: the role of synoviocytes. Rheum Dis Clin North Am 2001;27:355-71.

25 Pap T, Muller-Ladner U, Gay RE, Gay S. Fibroblast biology. Role of synovial fibroblasts in the pathogenesis of rheumatoid arthritis. Arthritis Res 2000;2:361-7.

26 Pilling D, Akbar AN, Girdlestone J, Orteu CH, Borthwick NJ, Amft N, et al. Interferon-beta mediates stromal cell rescue of $\mathrm{T}$ cells from apoptosis. Eur J Immunol 1999;29:1041-50.

27 Shouda T, Yoshida T, Hanada T, Wakioka T, Oishi M, Miyoshi K, et al. Induction of the cytokine signal regulator SOCS3/CIS3 as a therapeutic strategy for treating inflammatory arthritis. J Clin Invest 2001;108:1781-8.

28 Bromberg JF, Horvath CM, Wen Z, Schreiber RD, Darnell JE Jr. Transcriptionally active Stat1 is required for the antiproliferative effects of both interferon alpha and interferon gamma. Proc Natl Acad Sci USA 1996;93:7673-8.

29 Kumar A, Commane M, Flickinger TW, Horvath CM, Stark GR. Defective TNF-alpha-induced apoptosis in STAT1-null cells due to low constitutive levels of caspases. Science 1997;278:1630-2.

30 Lee KY, Anderson E, Madani K, Rosen GD. Loss of STATI expression confers resistance to IFN-gamma-induced apoptosis in ME180 cells. FEBS Lett 1999;459:323-6.

31 Krause A, Scaletta N, Ji JD, Ivashkiv LB. Rheumatoid arthritis synoviocyte survival is dependent on Stat3. J Immunol 2002;169:6610-16. 